\title{
The impact of information technology on open urban space: the case study of Taksim square
}

\author{
B. Souici \\ Ecole polytechnique d'architecture et d'urbanisme, EPAU, Algieria
}

\begin{abstract}
For centuries, city centres have provided liveability for much of urban life: shopping, civic activities, leisure, or simply for meeting and mixing. Today, city centers face real challenges; they must respond to the changing needs and demands of modern-day living; squares need to prosper in order to survive. They must compete effectively with the advances in the means of technological communication. They have always faced a degree of competition throughout their historical past, but in the last ten years the competition has increased markedly. Each square has a distinctive shape and personality. That is what makes them so rewarding to experience and so difficult to create. Vintage squares remind us of an era when good design was instinctive, and cities had a rich street life. People have always enjoyed coming together; even though this task can be accomplished by means of virtual space, the need for verbal and physical contact remains primordial and necessary. Networks, deliver information whenever and wherever people desire and allow to perform many activities without moving in the space; banking, bill-paying, shopping. Gathering places are no longer attractive; public life seems to be slipping away along with public open spaces. Dematerialization, decentralization and demobilization are factors which result from information technology use. A new urban strategy has to be implemented, and new directions have to be designed for the vitality of future urban open spaces. This new social tendency generates strategic urban relationships, processes and patterns that will form and maybe reshape public open space and its surroundings.
\end{abstract}

Keywords: urban open space, Taksim square, information technology, urban space motion. 


\section{Introduction}

Throughout history, the public open space has always been subject to transformation, in both its identity and in the activities held there. Some activities moved from outdoors to indoors, leaving the space free for other activities, and others disappeared completely under conditions existing at the time. A square which is in direct and permanent contact with citizens certainly changes in activities and shape. But, in essence remains the same. Main features of the society are reflected in these spaces, they exist not only in the present but also incorporate the past (Batten [1]. Zucker [2], Canter [3] and Carr [4]). History shows us that the square is a place where changes are rapidly felt. Information technology, through the facilities it offers, is creating new behaviour in social moods, which is transmitted through the actions of citizens. At this stage it is peculiar to the issue of the activities of the square. Under these circumstances, this study aimed to clarify the relationship which exists between information technology (as the causative part of the phenomenon) and the vanishing or substituted activities in public open space (as the result of the phenomenon). At this stage it is worthwhile to level some questions, with the intention of defining the key words for solving the phenomenon:

1. What are the activities which have disappeared or will disappear from today's square, and by which activities will they be replaced?

2. How would it be possible to make the square attractive without changing its identity?

\section{Scope of the study}

The scope of the study is limited to the activities which affect the square, and how they would be materially translated on the square.

Showing the degree of the effectiveness of rapidly changing information technology on the square necessitates a case study on which the pre-stated hypothesis will be projected. Taksim Square was selected as the case study area. It was chosen from among the large number of rival squares in Istanbul for the following reasons:

First, its architectural characteristics; it corresponds to the square-determined character by its shape; it is limited by public elements, streets and boundaries. It has self-contained elements such as its monument and public services such as PTT, telephone banks and transportation facilities.

Second, throughout its history, from the 17 th century when it was a simple empty field for cannon-firing exercises, through its life as a gathering place at the end of Ottoman Empire, to a ceremonial venue during the Republican period, it remains, through its past and present, the most popular square in the city. Today it is a square connected worldwide via wire and wireless communication systems, reaching the different activities held there ranging from hotels, banks, shopping, and cultural facilities. On various occasions different events have been held in the square, such as festivities, workshops and fairs. Its transportation 
scale seems enormous, because it is levelled at the whole city stage. Introducing metro service at the heart of the square has added the potential and capacity for receiving greater numbers of citizens and consequently the services that have to be offered to them. At the scale of the city it would not be possible to test how the use information technology acts, so it is logical to start from a welldetermined size such as a square, where the boundaries are delineated and the activities are known. The results which could be obtained from the Taksim Square test would be generators for subsequent studies on other public spaces and later at the whole city.

\subsection{Late Ottoman Empire period (1850-1923)}

The present Taksim Park was a place for military training; there were garages facing Cumhuriyet Caddesi, meant to hold all sort of weapons and trucks. On Ramadhan days three cannon shots were fired to announce sunset time. This vast field held many important exhibitions during the Ottoman Empire. For instance, in 1918 at the end of the First World War, Austrian Emperor Karl supervised military conditions and attended a memorable march for his honour. The area around today's Taksim Square fountain and monument was very animated during the last days of the Ottoman Empire, the crowds originating from the Grande rue de Pera. This place was used also as a market for motor-bikes and bicycles on Sundays. Some images of daily life at that time were transmitted by a French orientalist, Theophile Gautier, who had visited Istanbul in 1852 and wrote about his experiences. He had visited the Beyoğlu quarter and said, "At the end of la Rue de Pera we arrived at a shaded fountain, close to that fountain horses renters offer their services in three languages: Ottoman, Italian and French; on the other side barouches waiting to be filled then could take the Pera or the Şişli direction. Iced water sellers, blackberry, cucumber, cake and candy drew the attention of large clienteles Groups of women were sitting by the edge of the road and looking at the crowd of Turks, Greeks, Armenians, Persians, Bulgarians and Europeans walking up and down the Grande Rue de Pera" (original text in the French language, Gautier [5]). Cafés were located near the artillery barracks, where songs and a drum were played. On the artillery esplanade, horse show parades started, and spectators were excitedly delighted. Late at night Karagöz theatre was played close to the fountain; the audience present sat on stools, and the performances could last until daybreak. A luxury imported barouches shop was opened at that time, which stayed in business until the 1920s. In general, every high technology was available at that time, permitting citizens to get information rapidly and freely.

Verbal behaviour also performed this function, with information reported from one person to another; gathering places served many different functions at the same time. For instance, cafés were mostly used to discuss politics and new happenings in the city, rather than just as a place to drink coffee. At the square a café existed in the location of the current post office, which Gautier tells us was mostly frequented by Greeks and Armenians. Thus, every café had its proper clientele and specific atmosphere about it; citizens came there to give and take information, apart from its original function (Gautier [5]). Tramlines were 
introduced to Istanbul in 1869, one of them running from Eminönü in the old city and across the Galata bridge to Karaköy and then along the shore of the Bosporus, while another ran along the Grande Rue de Pera. Then, in 1876, a French company inaugurated the underground funicular railway known as Tunnel, taking passengers from Karaköy on the Golden Horn to the heights of Pera, thus providing a link between the two trolley lines. The upper entrance of the Tunnel was the southern terminus of the tramline along the Grande Rue de Pera, which in the early republican era was re-named Istiklal Street. This service began as a horse-drawn tram when the Tunnel opened in 1876, and became an electric trolley in 1913. The tramline ran northward along the avenue, stopping en route at Galatasary Square, and ending at Taksim Square, where the cars turned around. The establishment of the tramway was a new event that gave a reason for Taksim Square to fill with buildings and social activities (Gülersoy [6]). Electricity was first used in Istanbul on $14^{\text {th }}$ February 1914 , and filled the Taksim nights with light and animation. The use of electricity brought electrical machinery as well, but it was not immediately evident in the early years.

\subsection{Era of the new republic (1923-1940)}

The passage from the Ottoman era to the Republican one was remarkable in the matter of giving and getting information at the square: posters were hung on the water depot wall. Citizens came to learn about the government and the news of the war. Radio was an alternative source for those who possessed them. The Modernist movement start to have its effect on the manner in which the city was designed, and Taksim Square wasn't spared those changes. In 1926, a workshop commission was formed to decide on the financial and technical supplier for the victory monument. Finally, the Italian sculptor Professor Pierto Canonica was selected to realise the monument. The contract was signed between Canonica and Muhittin Bey, specifying the duration of 18 months maximum and a cost of 16,500 pounds (Gülersoy [6]).

The monument is 11 meters in height, completely made of Italian marble; a mixture of Trentino red marble and Suza green. It weighs 184 tons, the face in the Harbiye direction symbolises the 30 August victory, while the face directed toward Galatasaray represents Republican Turkey. A few years later the waterfall wall was built in the Republican 1930s style; just behind it the Taksim water depot is located, a construction dating from Ottoman Empire days, rectangular in shape, 17 meters wide and 90 meters long. The waterfall wall came to replace the posters wall, which was at the last days of Ottomans. Since the waterfall wall was built, all the area close to it has been kept free from any function, either commercial or cultural. Thus the Karagöz theatre no longer existed during the Republican period; it might have moved far from the square but no data about its location is available. One of the most impressive images of the Republican era was the spread of the new Turkish alphabet immediately after the speech of Ataturk. In the late 1920s the vacant area across from the barracks that was used for drills gradually filled with apartment houses. The barracks were vacated in the 1920s and 1930s. Its courtyard was used for some time as a soccer field, but the structure was entirely demolished during the 
development operation that began in 1939 and lasted for a few years during the term of Lütfi Kırdar as mayor. In the 1920s, the Ayaspaşa graveyard was razed, allowing the extension of the present day apartment blocks toward the Gümüşsuyu Military Hospital, Gullers.

On one side of the square a residence had been built in the $19^{\text {th }}$ century for the foreign manager of the city power administration. The three-storey building was demolished after World War II, and later replaced by the present-day Atatürk Cultural Centre (Pervititch [7]). The $19^{\text {th }}$ century had witnessed the construction of several other significant buildings on the eastern side of the square. The first of these was the beautiful baroque mansion that was allocated to the French general manager of the Ottoman Bank at the site where the Marmara Hotel stands today. Aligned with this, toward Siraselviler Avenue was a series of stonework houses with shutters, the largest of which belonged to Noradunkuyan, an eminent figure in the Ottoman diplomatic corps. Where the Taksim site of the state theatre stands today, there was a Greek school. The cinema house that opened here in the early 1920s under the name of Majik has survived to our day, despite the changes in its name and function. In the 1930s the Kristal nightclub, a building raised on concrete columns, was erected on the western side of the square in front of the apartment blocks of Talimhane. In the early Republican era, Taksim Square was seen as a symbol of the new Turkish state. The national ceremonies held at the Monument of the Republic, the custom of laying wreaths at the monument, the parades before the platforms that were placed around the Inönü esplanade, which was designed in 1940 in place of the old barracks (National Geographic [8]).

Modernism had affected even the design of cafés; tables and chairs were arranged in the open air, a la francaise. Street goods sellers were no longer authorised to work at the square. All those new criteria had made of Taksim a disciplined square, with everything in order.

\subsection{Features of the square from 1940 to 1960}

At the end of the 1930s, the artillery barracks were entirely demolished during the development operation that began in 1939 and lasted for a few years during the term of Lütfi Kırdar as mayor. The parades were held before the platforms that were placed around the Inönü esplanade, which was built in 1940 in place of the barracks. The coloured bulbs around the monument forming strips of light at night have attracted the inhabitants of the city to the square for 25 to 30 years. Thus military activity ceded its place to green space and entertainment, but the principle remained the same: parades and shows were held in the same place but in the style of new republic [5, 6]. Remarkable posters and advertisements attracted the crowds of people when they passed by. Functions around the square changed; one of two residences of two Lebanese brothers, Necib and Selim Melhane, renowned viziers of the Abdulhamid II period 18761909 , on the left of the sloping Kazanci Road, was first converted into the Beyoğlu Cultural Centre in the 1930s, then demolished in the 1950s and replaced by the present-day Dilson Hotel. The mansion on the right toward Cihangir, 
originally was the residence of the Nemlizade Family, but it was later demolished, too, and the Keban Hotel was constructed on its site.

Toward the end of the 50s the square started to become the refuge of tourists, where they could discover the modern part of Istanbul. With the advent of tourists, new activities arose on place, such as modern cafés and photographers at the Republic monument. During interviews conducted with experts, among them Prof. Dr. Afife Batur, we are told that the most important building at the square in the 1950s was the Kristal Casino, where weddings were held. A European style cafe was located on the street level of the Kristal building, and people gathered there to watch the activity in the square and discuss daily events. She confirms that the Kristal building was one of the important buildings forming the three dimensional character of the square. Prof. Dr. Ayten Çetiner, another of the professors who had good information about the square and its evaluation, remembers that on religious as well as national holidays, a big crowd of people came to watch the changing colours of the water show created by the water administration. The same event was recounted by Prof. Dr. Fülin Bölen. Taksim Square and the promenade of Istiklal was the favoured area for political meetings and protests from the 1950 s on. M. Namık Doğu affirmed that on $4^{\text {th }}$ December 1944 a protest against Russia and its communist system was held by a group of intellectuals and students with the government's permission. In 1957, a protest against Greece was held in the square up to the sidewalks of Istiklal. Prof. Dr. Afife Batur also confirms that in the 1950s a different atmosphere reigned in the square; that of political demonstration. The Kristal Casino of the 30s was demolished during the development operation of Prime Minister Adnan Menderes which took place between 1956 and 1960. The entertainment clubs moved to the back streets of Istiklal.

\subsection{Taksim Square from 1960 to 1970}

The transformation that occurred to the square's form and buildings had affected activities held there. The destruction of the Kristal Casino and the decision to open the Tarlabaşı Boulevard to motor traffic had transformed the square's image and function. Most of interviewed professors confirm that the three dimensional victory element, was realised according to the surrounding buildings existing at that time. Once those buildings were demolished or replaced by higher ones, the monument lost its connection to its surroundings. Concerning the square itself, the demolition of the Kristal Casino and the opening of a boulevard had turned the square into an open place; architecturally nondetermined space. The lack of stability in the square's form and elements was under political decision. Ceremonies were held in the square as usual, but the presence wasn't too important, as it remains today. Methods of information weren't effective in attracting a large public presence.

\subsection{Taksim Square from 1970 to 1980}

The absence of the Kristal Casino was remarkable; they tried to mask it by large scale advertisement but this wasn't effective. The 70s were the years of man's rights, and most colonised countries gained their independence. This movement 
had reached all parts of the world; globalisation had started to become a part of the daily life of different nations all over the world. These groups had the same demands: peace, freedom, human rights and preserving nature; even though they were far from each other geographically they were connected in ideology. That was the case with the 1977 Taksim Square events, where workers organised a meeting on $1^{\text {st }}$ May to bring attention to the workers' problems, but unfortunately it ended with bloody opposition. Here also we notice the role of the square as a venue for the different changes occurring in society, and we see how it could be used at those moments. During the mid-1970s the Marmara Hotel was built; that was totally an economic objective. When it first opened for service in 1975, it was managed by an American hotel group, and named "Intercontinental". At the site of the Marmara Hotel, there was a remarkable stone building: the Osmanl Bank, a mixture of Vienna and Beyoğlu style. Immediately after it, in the direction of Siraselviler, stood the mansion of the General Director of Osmanl1 Bank. The second building in this series was an English peer's home, and next to it a two storey building famous in the 1930s and the 1960s: "Ankara Pazari" owned by a Greek family called Kirku. That two storey building was similar to today's markets.

All the above-mentioned buildings were demolished in order to be replaced by today's Marmara Hotel.

\subsection{Taksim Square from 1980 to 1990}

The blocks behind the Kristal Casino were torn down in 1987 when Mayor Bedrettin Dalan enlarged the Tarlabaşı Boulevard. Their sites were added to the square and the road. An increase in vehicle flow was the reason for the demolitions and enlargements. The building of the Marmara Hotel added to the square support for the tourist industry. Even though the $80 \mathrm{~s}$ were characterised by the diffusion of new television channels, it didn't have any effect on the square. The most important building to come to the square was the Ataturk Cultural Centre, and with it came a new notion of the square. The cultural centre was the favourite of citizens in the 1980s; they came to attend classical opera performances and mostly classical music concerts. The crowd before and after scene was remarkable; the edifice was scaled at the city level and moreover had given an architectural limitation to the square with its linear façade, even though it didn't work with the whole panoramic view of the square. That was one of the architectural problems of the 1980s: proportions between buildings were no longer respected, as though each building was designed as an isolated project without considering the space as a whole. The 1980s were characterised by the conversion of Istiklal Avenue into a pedestrian walkway in 1989, and that decision helped to encourage street activities. By separating pedestrian and vehicular traffic, the street life started to be regained. The free space left by vehicular traffic was used for street activities.

\subsection{Taksim Square under the effect of information technology (1990-2003)}

The 1990s brought information technology devices to the square. Internet use reached its climax in 1990, affecting the different activities located in the square 
ranging from education, cultural, and tourism to commerce and finance. The bank machine has been a familiar element in the square since 1994. As a first step, let us state the actual situation in the square, in order to extract the different activities located there. The most important building with its iron and glass façade is the AKM (Atatürk Cultural Center) building, then in the direction of Ayazpasa, is the İs Bank with its ATM machine. In the direction of the monument, first on the corner is Vakıf Bank with two ATM machines, then the Marmara Hotel, in place since 1972. On the street level of the hotel is a café, then the Garanti Bank with its ATM machine at the corner of the building. The akbil and IETT ticket sales point is one of the facilities provided by information technology; it has become a daily scene in the square to see people asking for tickets or getting their akbil refilled. Today we count:

1 Akbil (smart card) sales point;

2 IETT (Istanbul Electric Tram and Tunnel ) ticket sale points;

1 sales point for Akbil and İETT tickets;

32 phone booths near the bus terminal, in front of the PTT office;

16 phone booths at the beginning of Istiklal Avenue.

A remarkable new physical element in the square that attracts the curiosity of citizens is the Canal D live camera, where people come to sing songs or imitate famous persons or even confess a secret to the whole public. The square transportation is assured by public bus services and the underground rail (Metro), which has been in service since the 16 September 2000, linking Taksim to 4 . Levent. Activities in the square are various, but can be classified into four important categories: cultural, hotel, finance-banking and commerce. The most important cultural building in the square, is the Atatürk Cultural Centre (AKM). Activities held in this building are monthly, weekly and even daily posted on net pages. One of the most popular web pages interested in the AKM activities is the Biletix web page (www.biletix.com). Cultural activities are classified in four categories: sports, concerts, art and cinema; by clicking on one of the above categories a monthly schedule appears on the screen, then you can ask for the ticket. Another way to learn about cultural activities at AKM is through www.bigglook.com, which is similar to the previous one, giving detailed information about the time and place of the requested cultural activity.

The degree of effectiveness of information technology differs from one country to the other and from one place to the next. The result of isolation and the mortality of public life was felt as early as 1992 . For a person who uses the internet for almost 8 hours per day, it seems as if it is hard for him to do other thing after work time. Internet use consumes not only the interest of citizens but also their time of being in the open air, or being in a public space. Most people are not conscious of what is changing in themselves and the direction they are going. The consequence is properly a social problem; in the next and immediate stage it will affect the surroundings, the space and outdoor activities. The internet café is replacing the traditional café; chat group rooms are replacing outdoor neighborhood gathering places. 


\section{Impact of the internet in Turkey}

Wireless message communication and internet facilities ease our daily life in such manner that when asking for information or services, it is no longer necessary to move or commute from one space to another. Within the use of the internet, the notion of location as a physical space doesn't have any weight. In our case, we are interested in the public open space activities issue within the framework of internet use as a means of communication.

Firms, companies, establishments, schools and universities, hotels and certainly banks are 24-hour internet connected. It is necessary to look into the type of activities done via the internet in these locations. This kind of mass services affect, on the first level, small markets and district markets, and consequently that affects the use of public space because it is the transit area between the individual and the market. Schools and universities were the first establishments affected by internet use. For instance, Istanbul Technical University library services are available on www.library.itu.edu.tr; before coming to the library the user can learn about what is available on. Enrolment in the university is also one of the services available on www.fbe.itu.edu.tr; it would be an easy and instant task to enrol from wherever you are in the world. Once again, the role of public space is taken over by the internet facilities. Hotels also opt for the internet for reservation and payment. A client can book a hotel room without the help of a coordinating agent. Banking is the sector most affected by the internet. In the following table the progress in online filial (is shown as well as ATM and POS), the number is for total Turkey.

In table 1, we can check out that the bank and finance sector is going virtual, through the use of online branches, ATM machines dispersed all over the city and POS (post of sale machines for credit cards) which is movable and available in most supermarkets. First of all, the amount of shopping done by credit card from 1994 to 2000 led to the disappearance of money as a touchable material, and consequently that affects small commerce or, let us say, street trade and the week end market. Certainly, that has a relation with individual income and the social level in which one is living, and without any doubt the individual awareness of information technology advantages. The continuous information technology use in the banking sector creates a decentralisation of activity; it is no longer necessary that the central bank be in the downtown area as it was years ago.

Internet networking has led to the banking sector, in terms of building and location, to be installed far from the city centre because most services are available online or assured by branch and ATM machines. The other sector affected by information technology is PTT services: the PTT office was always one of the important buildings in the square. With the advent of the internet in 1993 and especially the availability of email, the necessity of sending letters was highly restricted for individuals; of course, the case is different for state establishments that do not accept email as official documents. Even the payment of bills, which can be done automatically via salary deduction or by the internet, has largely affected the activity in PTT offices. 
Table 1: Impact of information technology on the banking sector [9].

\begin{tabular}{|l|l|l|l|l|l|}
\hline & 1980 & 1990 & 1994 & 1999 & 2000 \\
\hline Number of banks & 43 & 66 & 67 & 81 & $79 / 67$ \\
\hline Number of branches & 5,954 & 6,560 & 6,087 & 7,691 & 7,837 \\
\hline Number of online branches & - & - & - & 6,938 & 7,523 \\
\hline Number of ATM & - & 3,209 & 4,023 & 9,939 & 11,991 \\
\hline Number of POS & - & - & 16,135 & 188,957 & 299,950 \\
\hline Number of personals & 125,312 & 154,089 & 139,046 & 173,988 & 170,401 \\
\hline Number of credit cards (1000) & - & - & 1,564 & 10,045 & 13,408 \\
\hline Number of bank cards (1000) & - & - & 10,469 & 24,107 & 29,560 \\
\hline $\begin{array}{l}\text { Shopping done by credit card } \\
\text { (million USD) }\end{array}$ & - & - & 1,273 & 12,410 & 16,413 \\
\hline
\end{tabular}

In table 2, the 50\% decrease in letter box numbers between 1992 and 1993 would be simply explained by the first appearance of the internet. The number continued to decrease until 1995, when internet use was widespread in Turkey. In the following years the number remains steady for almost 5 years, reflecting the public's decision concerning letter boxes. Internet use first affected inside PTT office activities, and afterward the number of the offices themselves. It is apparent that the effectiveness of internet use started from the base to reach the top, first affecting box mail and bill payment, then the office itself. In the next table in which the number of PTT offices decreased from 1,786 to 1,107 between 1994 and 1995 in Istanbul, during the same period the number decreased from 34,692 to 31,222 for all of Turkey. In Istanbul the decrease was dramatic in comparison to the whole country, because Istanbul represents $60 \%$ of all internet users of the country (Table 3 ).

Table 2: Number of letter boxes in Turkey [10].

\begin{tabular}{|l|c|c|c|c|c|c|c|c|c|c|c|}
\hline Year & 1990 & 1991 & 1992 & 1993 & 1994 & 1995 & 1996 & 1997 & 1998 & 1999 & 2000 \\
\hline $\mathrm{Nb}$ & 69383 & 69706 & 69411 & 39897 & 39897 & 38897 & 40269 & 40269 & 40269 & 40269 & 40269 \\
\hline
\end{tabular}

Table 3: $\quad$ Number of PTT offices [10].

\begin{tabular}{|l|c|c|}
\hline Year & Istanbul PTT offices & Turkey PTT offices \\
\hline 1991 & 2,177 & 41,916 \\
\hline 1992 & 2,282 & 41,623 \\
\hline 1993 & 1.987 & 40,124 \\
\hline 1994 & 1,786 & 34,692 \\
\hline 1995 & 1,107 & 31,222 \\
\hline 1996 & 1,107 & 24,860 \\
\hline 1997 & 1,107 & 19,063 \\
\hline 1998 & 1,107 & 16,984 \\
\hline 1999 & 1,107 & 13,631 \\
\hline 2000 & 1,107 & 5,605 \\
\hline
\end{tabular}


The role once played by PTT offices today is filled by a bouquet of internet sites. The PTT office only yesterday was an important element in the square in terms of its physical space and activity; this is no longer the case. It may not disappear completely, but gradually it will be replaced by other physical elements (machines).

\section{Conclusion}

Within the last ten years information technology has progressed rapidly, and becomes indispensable for the daily life of the citizen. Through observing Taksim Square, a new scene of people's behaviour is arising in place, the notion of space is no longer well-identified for citizens; the limits of the square can go beyond its physical edges.

Citizens are no longer aware of landmarks in the square, because information technology devices create another dimension of landmark that can range from punctual element to beyond the square limits. People's behaviour is changing by assuming new technology devices; this change is spontaneous and rapidly materialized in space, in the form of physical elements; such as ATM Machines, smart bill machines, TV cameras etc. All interviewed persons confirm that they use the internet for buying concert tickets. A cultural centre continues to exist but only in the sense of giving performances, and the commercialisation is undertaken on the net. The overall effect of electronic devices is to partially substitute the previous stated activities, and that affects directly the form and volume of the concerned buildings. In the next stage it creates dematerialization and even deconstruction if it is needed. The use of internet facilities has limited people's daily movement; in general, moving bits is immeasurably more efficient than moving people and goods. A promising strategy for polycentric cities interconnected by efficient transportation and electronic facilities, less use of mechanical vehicles, more use of pedestrian paths assuring links between citizens and service facilities, will depend on the possibility of electronic connection and no more on its localisation in the city. Decentralisation of the city centre, activities through the net are adequately distributed, wherever you would be your request is achieved. That opportunity allows us to create a new strategy for the urban design of the city of the future: the city will be no more a whole, but a group of fragments interconnected to each other by an efficient transportation infrastructure and electronic facilities. Those city fragments would be self-contained and totally independent from centralization links; in fact this situation is actually felt through the questionnaire results, where interviewed persons confirm that they would be in the city centre because their work or school is located there. In this case, the city square has to be more attractive than it was before, and that would be possible by organizing workshops and fairs. New IT devices could be organised in a different form providing more efficient and secure use in the space and bring a new urban open space image. 


\section{References}

[1] Batten, D, F., Network Cities, Creative Urban Agglomerations for the 21st Century, Urban Studies, Vol. 32, No. 2, pp. 11-12, 1995.

[2] Zucker, P., Town and Square, from The Agora to The Village Green, Cambridge, London., The MIT Press, Massachusetts, pp. 22-42, 1970.

[3] Canter, D., The Psychology of Place, St Martin's Press, New York, 1977.

[4] Carr, S., Public Space, Cambridge University Press, England, pp. 26-48, 1992.

[5] Gautier, T., Constantinople, Istanbul en 1852, Texte Présenté et Annoté par Jaques Huré, Publié par Les Edition ISIS , Şemsibey Sok 10, 81210 Beylerbeyi, Istanbul, pp. 86-155, 1990.

[6] Gülersoy, Ç., Taksim Bir Meydanın Hikayesi, Istanbul Kitaplığı Ltd, pp. 38-112, 1986.

[7] Pervititch, J., Istanbul in the insurance Map of Jaques Pervititch, Axa Oyak, pp. 123-128, 2001.

[8] National Geographic Magazine., Deniz Erdem., pp. 23-25, February 2000.

[9] http://www.bddk.org.tr., February 2003.

[10] PTT Statistics 2000, Ankara. 